\title{
Mortality of two groups of women who manufactured gas masks from chrysotile and crocidolite asbestos: a 40-year follow-up
}

\author{
E D ACHESON, ${ }^{1}$ M J GARDNER, ${ }^{1}$ E C PIPPARD,${ }^{1}$ AND L P GRIME ${ }^{2}$ \\ From the MRC Environmental Epidemiology Unit, ' University of Southampton, Southampton \\ General Hospital, Southampton SO9 $4 X Y$, and Lancashire Area Health Authority, Pendle and Rossendale ${ }^{3}$ \\ Burnley General Hospital, Burnley BB10 2PQ, UK
}

ABSTRACT Two groups of women were exposed to asbestos while manufacturing gas masks in Lancashire before and during the second world war. One group (in Blackburn) is believed to have been concerned almost exclusively with the manufacture of civilian respirators (containing chrysotile) while the other (in Leyland) made respirators for the armed Forces (containing crocidolite) and a much smaller number of civilian respirators. Excess mortality ascribed to lung cancer and ovarian cancer were found at the second factory (statistically significant at the $1 \%$ level) but not at the first. Mesothelioma was mentioned on the death certificates of five women who had worked in Leyland and one woman in Blackburn.

The starting point of this study was an attempt to define two populations similar in other ways, exposed respectively to crocidolite and chrysotile asbestos in the manufacture of gas masks. It was known that the standard respirators issued to the armed Forces of the British Commonwealth before and during the second world war contained filters consisting of activated charcoal, merino wool, and West Australian crocidolite. ${ }^{1}$ Studies of the mortality of factory workers employed in manufacturing Service respirators in Nottingham, England, and Ottawa, Canada, have been published..$^{1-3}$ Both groups of workers have suffered from excess mortality due to mesothelioma of the pleura and peritoneum. A study of women who worked in the Nottingham factory has also shown excesses of cancer of the lung and ovary. ${ }^{4}$

In Britain respirators were also manufactured to protect the civilian population. A contract was placed with a factory in Blackburn, Lancashire, in 1936 to manufacture more than 70 million civilian gas masks and work continued in this factory until the end of the war. From contempory data (Ministry

\footnotetext{
Requests for reprints to: Professor E D Acheson.
}

Received 14 December 1981

Accepted 18 February 1982 of Supply, Home Office, and War Office papers 1927-45) and analysis of the contents of surviving masks, civilian gas masks are known to have contained chrysotile, charcoal, and merino wool but not crocidolite.

At Leyland, Lancashire, the same firm operated a factory that from 1927 held a monopoly for the manufacture of gas masks for the armed Forces. At an unknown date in the 1930s these respirators were modified to contain crocidolite, and gas masks of the improved type continued to be manufactured there throughout the war and thereafter. Industrial gas masks containing crocidolite were made there until 1969. From the testimony of workers it is known that some civilian gas masks containing chrysotile were also made during the war at the Leyland factory. Some workers travelled from Preston to work in the Leyland factory.

We describe the mortality during $1951-80$ of the two groups of female gas mask makers. The 570 women resident in Blackburn were working in 1939 at the factory that manufactured civilian respirators containing chrysotile. The 757 women resident in Leyland (435) and Preston (322) were engaged in 1939 principally in manufacturing Service respirators and had been exposed to crocidolite but also to some chrysotile. They are referred to hereafter, for convenience, as the Leyland group. 
Method

Using the National Health Service Central Register, staff of the Office of Population Censuses and Surveys searched the records of everyone resident in September 1939 at Leyland, Preston, and Blackburn. They identified those whose occupations at that time indicated that they were manufacturing gas masks. The vital status of these workers on 30 June 1980 was ascertained, and in the case of those who had died the date and cause of death was abstracted.

The main analysis was restricted to women, thus excluding the 95 men employed at Leyland and the 58 employed at Blackburn. The number of deaths expected in these women was calculated using the person-years method, ${ }^{5}$ and compared with the number observed. Deaths from 1 January 1951 to 30 June 1980 were included, and five-year age group cause-specific death-rates for five-year calendar periods were used to calculate the expected numbers. ${ }^{67}$ The rates used were for England and Wales as a whole, and an area correction was then incorporated into the analysis to adjust for local mortality during the years 1968-78. Although these years do not span the whole period of 1951-80 they

Table 1 Female gas mask makers by status, person-years of follow-up, and area

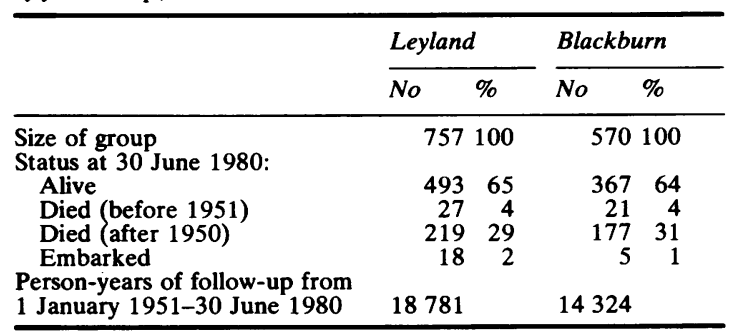

are the only ones for which rates for Leyland, Preston, and Blackburn are available. Tests of the statistical significance of the observed number of deaths compared with the numbers expected are based on the Poisson distribution.

The average age of each group of women in 1939 was 28.3 years, although the spread of ages was slightly greater in Leyland than in Blackburn (the standard deviations are 8.7 and 7.2 years respectively).

\section{Results}

Table 1 shows the basic follow-up information on the women in each area. A few left England and Wales during the period, and their vital status subsequent to embarkation is unknown. Also, the small number of deaths occurring before 1951 has been omitted from the main analysis as having only a short elapse time since exposure in 1939. Overall, about a third of each group have died, and most of those still alive were over 60 in 1980.

In table 2 the general mortality experience of the two groups of women during 1951-80 is set out. Both groups showed a statistically significant excess of deaths from all causes combined compared with the numbers expected on the basis of rates for England and Wales. In Leyland, after adjustment for local area mortality, this excess is principally due to deaths from cancer. On the other hand, for Blackburn there is only a slight excess of deaths from cancer, but there is a large increase in deaths from other causes. On breaking the latter down into individual causes the excess can be shown to be due to deaths from acute myocardial infarction (ICD No 410,8 th revision). ${ }^{8}$

Mortality from malignant neoplasms is given by site in table 3 for the leading causes of death from cancer in women. Only sites with more than five

Table 2 Mortality of female gas mask makers in Leyland and Blackburn between 1 January 1951 and 30 June 1980, and relation to local area mortality

\begin{tabular}{|c|c|c|c|c|c|c|c|c|}
\hline \multirow{3}{*}{$\begin{array}{l}\text { Cause of } \\
\text { death }\end{array}$} & \multirow[t]{3}{*}{ Area } & \multicolumn{5}{|c|}{ Gas mask makers } & \multirow{3}{*}{$\begin{array}{l}\text { Area } \\
\text { standardised } \\
\text { mortality ratio } \\
(S M R) \text { 1968-78 }\end{array}$} & \multirow{3}{*}{$\begin{array}{l}\text { Ratio gas mask } \\
\text { makers } S M R \text { to } \\
\text { area SMR }\end{array}$} \\
\hline & & \multicolumn{2}{|c|}{ No of deaths } & \multicolumn{3}{|c|}{ Standardised mortality ratio } & & \\
\hline & & Obs & $\operatorname{Exp}$ & $S M R$ & $L$ & $U$ & & \\
\hline All causes & $\begin{array}{l}\text { Leyland } \\
\text { Blackburn }\end{array}$ & $\begin{array}{l}219 \\
177\end{array}$ & $\begin{array}{l}185 \\
128\end{array}$ & $\begin{array}{l}118^{*} \\
138^{* *}\end{array}$ & $\begin{array}{l}103 \\
119\end{array}$ & $\begin{array}{l}135 \\
160\end{array}$ & $\begin{array}{l}110 \\
116\end{array}$ & $\begin{array}{l}1 \cdot 07 \\
1 \cdot 19^{*}\end{array}$ \\
\hline $\begin{array}{l}\text { All malignant } \\
\text { neoplasms }\end{array}$ & $\begin{array}{l}\text { Leyland } \\
\text { Blackburn }\end{array}$ & $\begin{array}{l}66 \\
44\end{array}$ & $\begin{array}{l}54 \\
41\end{array}$ & $\begin{array}{l}123 \\
109\end{array}$ & $\begin{array}{l}95 \\
79\end{array}$ & $\begin{array}{l}156 \\
146\end{array}$ & $\begin{array}{r}95 \\
103\end{array}$ & $\begin{array}{l}1 \cdot 29^{*} \\
1 \cdot 06\end{array}$ \\
\hline $\begin{array}{l}\text { Other } \\
\text { causes }\end{array}$ & $\begin{array}{l}\text { Leyland } \\
\text { Blackburn }\end{array}$ & $\begin{array}{l}153 \\
133\end{array}$ & $\begin{array}{r}131 \\
88\end{array}$ & $\begin{array}{l}117 \\
152^{* *}\end{array}$ & $\begin{array}{r}99 \\
127\end{array}$ & $\begin{array}{l}137 \\
180\end{array}$ & $\begin{array}{l}114 \\
119\end{array}$ & $\begin{array}{l}1 \cdot 03 \\
1 \cdot 28^{*}\end{array}$ \\
\hline
\end{tabular}

${ }^{*} \mathrm{p}<0.05,{ }^{* *} \mathrm{p}<0.01$

$\mathrm{L}=$ Lower $95 \%$ confidence limit. $\mathrm{U}=$ Upper $95 \%$ confidence limit. 
Table 3 Mortality from specific cancers of female gas mask makers in Leyland and Blackburn between 1 January 1951 and 30 June 1980, and relation to local area mortality

\begin{tabular}{|c|c|c|c|c|c|c|c|c|}
\hline \multirow{3}{*}{$\begin{array}{l}\text { Cause of } \\
\text { death } \dagger\end{array}$} & \multirow[t]{3}{*}{ Area } & \multicolumn{5}{|c|}{ Gas mask makers } & \multirow{3}{*}{$\begin{array}{l}\text { Area } \\
\text { standardised } \\
\text { mortality ratio } \\
(S M R) \text { 1968-78 }\end{array}$} & \multirow{3}{*}{$\begin{array}{l}\text { Ratio of gas mask } \\
\text { makers } S M R \text { to } \\
\text { area } S M R\end{array}$} \\
\hline & & \multicolumn{2}{|c|}{ No of deaths } & \multicolumn{3}{|c|}{ Standardised mortality ratio } & & \\
\hline & & Obs & $\operatorname{Exp}$ & $S M R$ & $L$ & $U$ & & \\
\hline Cancer of & Leyland & 5 & $4 \cdot 4$ & 114 & 37 & 267 & 91 & $1 \cdot 25$ \\
\hline stomach (151) & Blackburn & 4 & $3 \cdot 1$ & 129 & 35 & 331 & 157 & 0.82 \\
\hline Cancer of lung & Leyland & $15(2) \ddagger$ & $6 \cdot 2$ & $241^{* *}$ & 135 & 397 & 107 & $2 \cdot 25^{* *}$ \\
\hline$(162,163)$ & Blackburn & $7(1) \ddagger$ & $4 \cdot 8$ & 145 & 58 & 298 & 94 & $1 \cdot 54$ \\
\hline Cancer of & Leyland & 12 & $12 \cdot 4$ & 97 & 50 & 169 & 78 & $1 \cdot 24$ \\
\hline breast (174) & Blackburn & 11 & 9.5 & 115 & 58 & 207 & 91 & $1 \cdot 26$ \\
\hline Cancer of & Leyland & 4 & $3 \cdot 1$ & 128 & 35 & 329 & 134 & 0.96 \\
\hline cervix $(180)$ & Blackburn & 5 & 2.4 & 211 & 69 & 492 & 122 & $1 \cdot 73$ \\
\hline Cancer of & Leyland & 12 & $4 \cdot 4$ & $275^{* *}$ & 142 & 481 & 93 & $2 \cdot 96^{* *}$ \\
\hline ovary (183) & Blackburn & 5 & $3 \cdot 4$ & 148 & 48 & 344 & 85 & $1 \cdot 74$ \\
\hline
\end{tabular}

${ }^{* *} \mathrm{p}<0 \cdot 01$.

$\mathrm{L}=$ Lower $95 \%$ confidence limit. $\mathrm{U}=$ Upper $95 \%$ confidence limit.

$\uparrow$ Numbers in parentheses are 8 th revision ICD code numbers. ${ }^{8}$

$\ddagger$ Numbers in parentheses are deaths from pleural mesothelioma.

deaths are shown. There is a pronounced excess of deaths from lung and ovarian cancer in Leyland that is statistically significant after adjustment for local area mortality experience. If the two deaths from mesothelioma of the pleura at Leyland are excluded there remains an excess of deaths from lung cancer that is statistically significant at the $5 \%$ level. There was no excess mortality from cancers of the oesophagus, intestine, or rectum.

\section{MESOTHELIOMA}

Mesothelioma was mentioned on the death certificates of five women at Leyland and of one woman at Blackburn. In three of the Leyland cases (two pleural and one peritoneal) mesothelioma was the underlying cause of death and in one case (pleural) it was mentioned as a contributory cause; in the remaining case (peritoneal) the death had been coded to carcinomatosis. The Blackburn case of mesothelioma (pleural) was reported as the underlying cause of death. One additional death due to pleural mesothelioma was reported among the 95 men employed at Leyland, and two deaths in women (both at Leyland) were certified as due to asbestosis. By contrast with the four mesotheliomas certified as the underlying cause of death only 0.2 would be expected at the rates for England and Wales.

\section{TRENDS OF MORTALITY WITH TIME}

The figure shows the accumulated numbers of deaths since 1951 from cancer of the lung and cancer of the ovary in Leyland women compared with the accumulated expected numbers. For both types of cancer the observed numbers have risen faster than those expected, so that the size of the numerical excess has continued to increase over

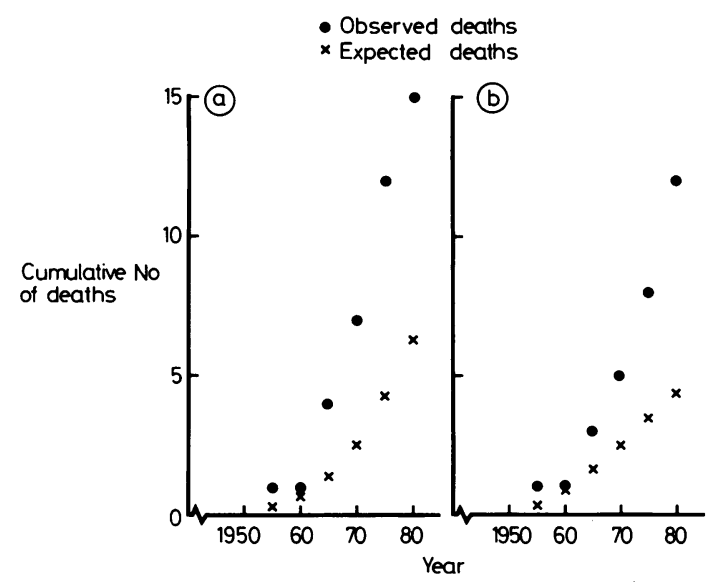

Accumulated deaths since 1951 in Leyland women from (a) cancer of the lung and (b) cancer of the ovary.

time up to 40 years after employment in the manufacture of gas masks. The increasing difference is particulary pronounced for ovarian cancer. Interestingly the deaths from mesothelioma in women all occurred after 1970-in 1972, 1974, two in 1975, 1978, and 1979-although the male mesothelioma death took place in 1961 .

\section{Discussion}

Two aspects of the findings of this study merit further discussion. These are the significant excess mortality ascribed to ovarian cancer and the differences observed between the experience of the Leyland and Blackburn workers.

Newhouse $^{9}$ was the first to suggest that there might be an association between exposure to asbes- 
tos and cancer of the ovary. A significant excess mortality (four observed deaths, 0.6 expected) from that cause was observed in her study of women exposed to chrysotile, amosite, and crocidolite at a factory in Barking that manufactured a wide variety of asbestos products, including the filters for both Service and civilian respirators. In a subsequent case-control study of patients with ovarian cancer exposure to asbestos was not identified as a risk factor. ${ }^{10}$ As none of the cases nor control patients had been exposed to asbestos, however, the population was inappropriate to test this hypothesis. Recently Wignall and Fox ${ }^{4}$ have shown a significant excess mortality from ovarian cancer in Nottingham women who manufactured gas masks containing crocidolite asbestos for the armed Forces during the second world war. The specification of these respirators is believed to have been similar to that of the Service gas masks manufactured at Leyland. No information is available about ovarian cancer in the Canadian gas mask makers but fewer than 100 women were exposed. ${ }^{3}$

The question must arise whether the excess numbers of deaths that have been attributed to ovarian cancer in this study and elsewhere have been correctly classified, or whether they represent cases of peritoneal mesothelioma. Deaths from peritoneal mesothelioma have also been reported in each of the populations of women factory workers mentioned above who had an excess of ovarian cancer. From the earliest descriptions of peritoneal mesothelioma the difficulties of the differential diagnosis vis-a-vis ovarian cancer have been emphasised. ${ }^{112}$ The clinical picture of secondary carcinomatosis of the peritoneum and of peritoneal mesothelioma is similar, and clinicians may be forgiven if the possibility of a rare industrially related tumour does not come to mind, particularly in a female patient. The chest radiograph does not always show evidence of previous exposure to asbestos in cases of peritoneal mesothelioma. ${ }^{13}$

A comparison between the mortality patterns of the Blackburn and Leyland workers shows that the significant excesses of mortality from lung and ovarian cancer (and all but one of the cases of mesothelioma) occurred at Leyland. If the study had been limited to Blackburn it would not have been possible to make a convincing case that there had been an excess risk of cancer associated with the manufacture of gas masks.

The probable explanation for the differences between Leyland and Blackburn lies in the different nature of the exposures in the two factories. The most obvious difference was that at Leyland crocidolite was the principal type of fibre to which the women were exposed while at Blackburn chrysotile was the only type of asbestos used. The other constituents of the filters-charcoal and merino wool-were common to both factories. There were other differences, however. The Service respirators at Leyland were made "by hand to a high standard" while at Blackburn, to cope with the massive order for civilian masks, manufacture was mechanised. The Leyland factory had been in operation longer before 1939 than had the Blackburn factory. Thus, in addition to the known differences in types of asbestos fibre in use in the two factories, there may also have been unknown differences in dose and duration of exposure. Nevertheless, the pattern of mortality is consistent with the view that mesothelioma (and possibly ovarian cancer) is particularly associated with exposure to crocidolite.

It should be pointed out that nothing is known of the industrial history of the women in the two cohorts before and after 1939. A second factory opened in Blackburn in 1941 to manufacture Service respirators containing crocidolite. According to the testimony of survivors this work was on a small scale, and there was little exchange between the two workforces. Several cases of mesothelioma are known to have occurred in this workforce (A J Maxwell, unpublished observations). Morgan and Holmes $^{14}$ have recently reported three cases of pleural mesothelioma at Blackburn in each of which amphibole asbestos fibre was found in samples of lung tissue. In two of these occupational exposure is stated as starting in 1941, the other being unknown. We have reason to believe that the Blackburn patient with pleural mesothelioma in our material transferred to the second Blackburn factory.

We would like to thank Dr C Osmond for his help with the computing work.

\section{References}

' Jones JSP, Pooley FD, Smith PG. Factory populations exposed to crocidolite asbestos-a continuing survey. INSERM 1976;52:117-20.

2 Jones JSP, Pooley FD, Smith PG, et al. The consequences of exposure to asbestos dust in a wartime gas mask factory. INSERM 1980;92:637-53.

${ }^{3}$ McDonald AD, McDonald JC. Mesothelioma after crocidolite exposure during gas mask manufacture. Environ Res 1978;17:340-6.

${ }^{4}$ Wignall BK, Fox AJ. Mortality of female gas mask assemblers. $\mathrm{Br} J$ Ind Med 1982;39:34-8.

${ }^{5}$ Hill ID. Computing man years at risk. Br J Prev Soc Med 1972;26: 132-4.

- Office of Population Censuses and Surveys. Cancer mortality, England and Wales, 1911-70. London: HMSO, 1975.

${ }^{7}$ Office of Population Censuses and Surveys. Cancer mortality in England and Wales, 1971-78. London: HMSO, 1980.

${ }^{8}$ World Health Organisation. International classification of diseases. 8th revision. Geneva: WHO, 1967.

${ }^{9}$ Newhouse ML, Berry G, Wagner JC, Turok ME. A study of the 
mortality of female asbestos workers. $\mathrm{Br} \mathrm{J}$ Ind Med 1972;29:134-41.

${ }^{10}$ Newhouse ML, Pearson RM, Fullerton JM, Boesen EAM, Shannon HS. A case control study of carcinoma of the ovary. Br J Prev Soc Med 1977;31:148-53.

"Swerdlow M. Mesothelioma of the pelvic peritoneum resembling papillary cystadenocarcinoma of the ovary. Am J Obstet Gynecol 1959;77:197-200.
${ }^{12}$ Keal EE. Asbestosis and abdominal neoplasias. Lance 1960;ii:1211-6.

${ }^{13}$ Chan PSF, Balfour TW, Bourke JB, Smith PG. Peritoneal mesothelioma. Br J Surg 1975;62:576-80.

14 Morgan A, Holmes A. Concentrations and characteristics of amphibole fibres in the lungs of workers exposed to crocidolite in the British gas mask factories, and elsewhere, during the second world war. $\mathrm{Br} \mathrm{J}$ Ind Med 1982;39:62-9.

\section{Vancouver style}

All manuscripts submitted to the $B r J$ Ind Med should conform to the uniform requirements for manuscripts submitted to biomedical journals (known as the Vancouver style).

The $\mathrm{Br} J$ Ind Med, together with many other international biomedical journals, has agreed to accept articles prepared in accordance with the Vancouver style. The style (described in full in Br Med J, 24 February 1979, p 532) is intended to standardise requirements for authors.

References should be numbered consecutively in the order in which they are first mentioned in the text by Arabic numerals above the line on each occasion the reference is cited (Manson ${ }^{1}$ confirmed other reports ${ }^{2-5} \ldots$. . In future references to papers submitted to the $\mathrm{Br} J$ Ind Med should include: the names of all authors if there are six or less or, if therc are more, the first three followed by et al; the title of journal articles or book chapters; the titles of journals abbreviated according to the style of Index Medicus; and the first and final page numbers of the article or chapter.

Examples of common forms of references are:

1 International Steering Committee of Medical Editors. Uniform requirements for manuscripts submitted to biomedical journals. Br Med J 1979;1:532-5.

2 Soter NA, Wasserman SI, Austen KF. Cold urticaria: release into the circulation of histamine and eosinophil chemotactic factor of anaphylaxis during cold challenge. $N$ Engl J Med 1976;294:687-90.

${ }^{3}$ Weinstein L, Swartz MN. Pathogenic properties of invading micro-organisms. In: Sodeman WA Jr, Sodeman WA, eds. Pathologic physiology: mechanisms of disease. Philadelphia: W B Saunders, 1974:457-72. 